\title{
Experimental Performance Analysis of an Automotive Air Conditioning and Heat Pump System using R134a with and without Internal Heat Exchanger
}

\author{
Erkutay TASDEMIRCI, Ertan ALPTEKIN, Murat HOSOZ
}

\begin{abstract}
In this study an experimental system was set up from the original components of an automotive air conditioning (AAC) system. After than internal heat exchanger (IHX) and reversing valve were installed to use as heat pump and improve performance of it. For each mode of operations, the system was tested at five different compressor speeds between 800 and 2800 rpm with intervals of $400 \mathrm{rpm}$. In the heat pump mode operations without IHX, the temperatures of the air streams entering the evaporator and condenser were maintained at $\mathbf{T}_{\text {evap,ai }}=0^{\circ} \mathbf{C}-\mathbf{T}_{\text {cond,ai }}=0^{\circ} \mathbf{C}$, $T_{\text {evap,ai }}=10^{\circ} \mathrm{C}-T_{\text {cond,ai }}=10^{\circ} \mathrm{C}$ and $T_{\text {evap,ai }}=15^{\circ} \mathrm{C}$ $T_{\text {cond,ai }}=15^{\circ} \mathrm{C}$. IHX was started up the temperatures of the air streams at the inlets of the evaporator and condenser were maintained at $\mathbf{T}_{\text {evap,ai }}=5^{\circ} \mathrm{C}-\mathbf{T}_{\text {cond,ai }}=5^{\circ} \mathrm{C}, \quad \mathbf{T}_{\text {evap,ai }}=10^{\circ} \mathrm{C}-$ $\mathrm{T}_{\text {cond,ai }}=10^{\circ} \mathrm{C}$ and $\mathrm{T}_{\text {evap,ai }}=15^{\circ} \mathrm{C}-\mathrm{T}_{\text {cond,ai }}=15^{\circ} \mathrm{C}$. Using experimental data, performance parameters such as conditioned air stream temperature, compressor power, compressor mechanical power and compressor discharge temperature were evaluated. In heat pump mode provided enough heating capacity and conditioned air stream temperatures even at low compressor speeds. Furthermore, the heating capacity increased but $\mathrm{COP}_{h}$ decreased with rising compressor speed however compressor power decreased and $\mathrm{COP}_{\mathrm{c}}$ increased with using IHX.
\end{abstract}

Keywords-HFC134a, automotive air conditioning, internal heat exchanger.

\section{Erkutay TASDEMIRCI}

Kocaeli University

Turkey

Murat HOSOZ

Kocaeli University

Turkey

\section{Introduction}

The thermal efficiency of modern diesel engines has increased significantly, thanks to recent advances in fuel injection systems. As a result, these high-efficiency engines cannot provide sufficient amount of waste heat for the comfort heating of passenger compartments in a short period of time once the engine has started up. More critically, because electric vehicles do not have a considerable waste heat source for comfort heating of the passenger compartment, they should employ another heat source. The problems of unavailability or lack of sufficient waste heat in vehicles for the aim of comfort heating can be solved by reversing the operation direction of the air conditioning system, thus operating it as a heat pump.

As a remedy to these problems, certain low cost components can be added to the present air conditioning system of the vehicle to operate it as a heat pump[1]. The automotive heat pump (AHP) system developed in this way can heat the passenger compartment individually, or it can support the present heating system of the vehicle.

The literature contains a few research studies on the AHP systems due to its competitive nature. Vargas and Parise [2] developed a mathematical model to predict the performance of a heat pump system with a variable capacity compressor. Antonijevic and Heckt [3] developed and evaluated the performance of an R134a AHP system, which was employed as a supplementary heating system. They found that the ratio of the heating capacity to the fuel consumption of the developed system was significantly better compared to other supplemental heating systems such as the glow plug heater and PTC heating system. Domitrovic et al. [4] simulated the steady-state cooling and heating operation of an automotive air conditioning (AAC) and AHP system. They found that R134a and R12 yielded comparable results, while the heating capacity of the AHP system was insufficient in both refrigerant cases.

Hosoz and Direk [5] evaluated the performance of an air-toair R134a AHP system, and compared its performance with the performance of the system operated in summer air conditioning mode. Rongstam and Mingrino [6] evaluated the performance of an R134a AHP system using engine coolant as a heat source, and compared it with the performance of a coolant-based heating system at $-10{ }^{\circ} \mathrm{C}$ ambient temperature. Lee et al. [7] conducted a study on the performance characteristics of a mobile heat pump for an electric bus using the wasted heat of electric devices as a heat source. Scherer et al. [8] reported an on-vehicle performance comparison of an R152a and R134a AHP system using engine coolant as a heat source. Direk and 
Hosoz [9] carried out an energy and exergy analysis of an R134a AHP system using ambient air as a heat source. They determined that the heat exchangers of the system were responsible for most of the exergy destruction. Tamura et al. [10] studied the experimental performance of an AHP system using $\mathrm{CO} 2$ as a refrigerant. They found that the performance of the system with $\mathrm{CO} 2$ was equal to or exceeding that of the system with R134a. Kim et al. [11] investigated the heating performance of an AHP system with $\mathrm{CO}$. They performed transient and steady-state tests under various operating conditions, finding that the use of their system improved heating capacity compared to the baseline heating system.

In this study, the performance parameters of an experimental AHP system with and without IHX for the cases of using the heat from ambient air was evaluated.

\section{Description of the Experimental Setup}

The experimental AHP system was made from automotive air conditioning system parts schematically shown in Fig. 1. It employed a seven-cylinder fixed-capacity swash-plate compressor, a parallel-flow micro-channel outdoor coil, a laminated type indoor coil, two thermostatic expansion valves (TXVs), a reversing valve to operate the system in reverse direction in the heat pump operations, Fig. 2 shows a photograph of the experimental AHP system. Table 1 indicates the specifications of the components used in the AHP system.

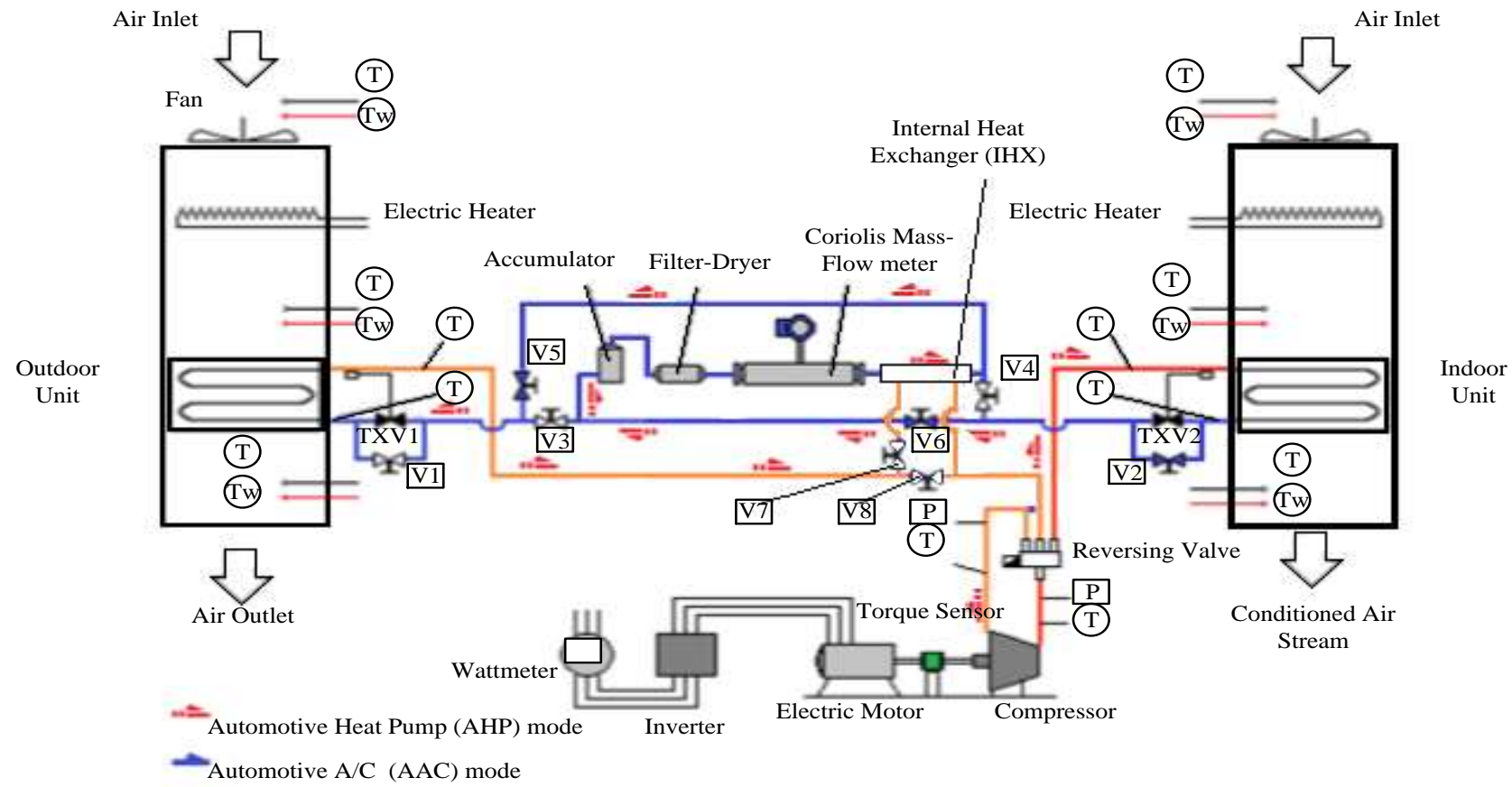

Figure 1. Schematic illustration of the experimental AAC/AHP system.

TABLE I. SPECIFICATIONS OF THE COMPONENTS OF THE AUTOMOTIVE HEAT PUMP SYSTEM

\begin{tabular}{|c|l|}
\hline Components & Specifications \\
\hline Compressor & $\begin{array}{l}\text { Type: fixed-capacity swash-plate, Stroke volume: } \\
155 \mathrm{cc}, \text { No. of cylinders: } 7 \text {, Max. Speed: } 6000 \mathrm{rpm}\end{array}$ \\
\hline Indoor unit & $\begin{array}{l}\text { Type: laminated coil, Capacity: } 5.8 \mathrm{~kW}, \\
\text { Dimensions: } 260 \times 230 \times 100 \mathrm{~mm}^{3}, \text { No. of } \\
\text { channels: } 23\end{array}$ \\
\hline Outdoor unit & $\begin{array}{l}\text { Type: parallel-flow micro-channel coil, Capacity: } \\
7.5 \mathrm{~kW}, \text { Dimensions: } 600 \times 400 \times 17 \mathrm{~mm}^{3}, \text { No. of } \\
\text { channels: } 42\end{array}$ \\
\hline TXVs & Type: internally equalized with bulb \\
\hline $\begin{array}{c}\text { Electromagnetic } \\
\text { Clutch }\end{array}$ & $48 \mathrm{~W}(12 \mathrm{~V})$ electromagnetic type \\
\hline
\end{tabular}

\begin{tabular}{|c|l|}
\hline Indoor unit fan & $100 \mathrm{~W}(12 \mathrm{~V})$ centrifugal type \\
\hline Outdoor unit fan & $2 \times 75 \mathrm{~W}(12 \mathrm{~V}) 300 \mathrm{~mm}$ diameters axial flow fan \\
\hline
\end{tabular}

The indoor and outdoor coils were inserted into separate air ducts of $1.0 \mathrm{~m}$ length. In order to provide the required air streams in the air ducts, a centrifugal fan and an axial fan were placed at the entrances of the indoor and outdoor air ducts, respectively. These ducts also contained electric heaters located upstream of the indoor and outdoor coils. The indoor and outdoor coil electric heaters could be controlled between $0-2.5 \mathrm{~kW}$ and $0-4.5 \mathrm{~kW}$, respectively, to provide the required air temperatures at the inlets of the related coils. The refrigeration circuit was charged with $2500 \mathrm{~g}$ of R134a. 
Some mechanical measurements were conducted on the heat pump system to gather data for performance evaluation of the system. The instruments and their locations are also indicated in Fig. 1. The refrigerant mass flow rates were measured by Coriolis mass flow meters, respectively. The temperatures measurement was performed by type $\mathrm{K}$ thermocouples and refrigerant pressures were measured by pressure transmitters. Most of the measured variables were acquired through a data acquisition system and recorded on a computer. The characteristics of the instrumentation can be seen in Table 2.

TABLE II. CHARACTERISTICS OF THE INSTRUMENTATION

\begin{tabular}{|c|l|l|l|}
\hline $\begin{array}{l}\text { Measured } \\
\text { variable }\end{array}$ & Instrument & Range & $\begin{array}{l}\text { Uncerta- } \\
\text { inty }\end{array}$ \\
\hline Temperature & $\begin{array}{l}\text { Type K } \\
\text { thermocouple }\end{array}$ & $\begin{array}{l}-50 \mathrm{to} \\
500{ }^{\circ} \mathrm{C}\end{array}$ & $\pm \% 0.3$ \\
\hline Pressure & Pressure transmitter & $0-25 \mathrm{bar}$ & $\pm \% 0.2$ \\
\hline Humidity & Hygrometer & $10-100 \%$ & $\pm \% 3$ \\
\hline Air flow rate & Anemometer & $\begin{array}{l}0.1- \\
15 \mathrm{~m} \mathrm{~s}^{-1}\end{array}$ & $\pm \% 3$ \\
\hline $\begin{array}{c}\text { Refrigerant mass } \\
\text { flow rate }\end{array}$ & Coriolis flow meter & $\begin{array}{l}0- \\
1300 \mathrm{~kg} \mathrm{~h}^{-1}\end{array}$ & $\pm \% 0.1$ \\
\hline $\begin{array}{c}\text { Compressor speed } \\
\text { Torque }\end{array}$ & Digital tachometer & $\begin{array}{l}10- \\
100,000 \mathrm{rp} \\
\mathrm{m}\end{array}$ & $\pm \% 2$ \\
\hline Voltage & Multimeter & $\begin{array}{l}-60-50 \mathrm{Nm} \\
\text { (AC/DC) }\end{array}$ & $\pm \% 0.05$ \\
\hline Current & Clamp ampermeter & $\begin{array}{l}-600-600 \mathrm{~A} \\
(\mathrm{AC} / \mathrm{DC})\end{array}$ & $\pm \% 1$ \\
\hline
\end{tabular}

The AHP system was driven a electric motor with a maximum power of $5500 \mathrm{~W}$ at $3000 \mathrm{rpm}$. The motor torque was measured by torque sensor of $50 \mathrm{Nm}$.

Fig. 1 also illustrates the refrigerant flow paths in the experimental heat pump system for the cases of using ambient air as a heat source. In order to perform the heat pump operation, the reversing valve is energized. Then, the reversing valve directs the high temperature superheated vapour refrigerant discharged from the compressor to the indoor unit (condenser). The refrigerant passing through the indoor unit rejects heat to the indoor air stream, thus providing a warm air stream to the passenger compartment. After rejecting heat to the indoor air stream, the refrigerant condenses and leaves the indoor unit as subcooled liquid. In heat pump operations, thermostatic expansion valve 1 (TXV2) is bypassed. Then, the refrigerant flows through the valves V2 and V6 and reaches the receiver tank, which keeps the unrequired refrigerant in it when the thermostatic expansion valve decreases the refrigerant flow rate at low loads. After passing through the filter/drier, sight glass, Coriolis flow meter and V5, the refrigerant reaches TXV1 located at the inlet of the outdoor unit. Since the valves V3 and V4 are closed, the refrigerant passes through TXV1, which reduces the pressure, and thereby the temperature, of the liquid refrigerant. TXV1 also controls the refrigerant mass flow rate circulating through the circuit so that a constant superheat at the outlet of the outdoor coil is maintained under all operating conditions. Next, it enters the outdoor unit, in which it absorbs heat from the outdoor air stream, and leaves this unit as low pressure superheated vapour. Then, the refrigerant passes through and enters the reversing valve. This valve directs the refrigerant to the compressor, which receives the low pressure refrigerant vapour and compresses it to a high pressure.

In order to operate the IHX in the heat pump system V7 and V8 valves must be opened. Refrigerant passes through in this valves and some of heat is absorbed from subcooled refregerant.

\section{Thermodynamic Analysis}

The performance parameters of the experimental AAC/AHP system can be evaluated by applying the first law of thermodynamics to the system. Using this law for the indoor unit (condenser) of the AHP system, the heating capacity of the AHP system can be evaluated from

$Q_{\text {cond }}=\dot{m}_{r}\left(h_{\text {condin }}-h_{\text {cond out }}\right)$

where is the refrigerant mass flow rate. On the other hand, by applying the first law of thermodynamics to the indoor unit (evaporator) of the AAC system, the cooling capacity of the AAC system can be obtained from

$$
Q_{\text {evap }}=\dot{m}_{r}\left(h_{\text {evap out }}-h_{\text {evapin }}\right)
$$

Assuming that the compressor is adiabatic, the power absorbed by the refrigerant during the compression process in both operation modes can be determined from

$W_{\text {comp }}=m_{r}\left(h_{\text {complout }}-h_{\text {compin in }}\right)$

The shaft power input to compressor can be evaluated from the motor torque and speed, i.e.

$W_{\text {comp, shaft }}=T \frac{\pi n}{30}$

The coefficient of performance of the AHP system is defined as the ratio between heating capacity and power input to the system, i.e.

$\operatorname{COP}=\frac{Q_{\text {cond }}}{W_{\text {in }}}$

where is the sum of compressor power and power inputs to the indoor unit blower, outdoor unit fan and compressor electromagnetic clutch.

The coefficient of performance of the AAC system, on the other hand, is defined as the ratio between cooling capacity and power input to the system, i.e.

$\operatorname{COP}_{c}=\frac{Q_{\text {evap }}}{W_{\text {in }}}$ 
The coefficient of performance of the AHP system based on compressor shaft power input as well as other power inputs to the system can be obtained from

$\operatorname{COP}_{\mathrm{h} m \mathrm{~m}}=\frac{Q_{\mathrm{cond}}}{W_{\mathrm{in}_{2} \mathrm{~m}}}$

where $W_{i n_{m} m}$ is the mechanical power input to the AAC/AHP

system, which is evaluated by summing up the shaft power input to the compressor and the power consumed by the fans of indoor and outdoor units as well as compressor electromagnetic clutch.

Finally, the coefficient of performance of the AAC system based on compressor shaft power input as well as other power inputs to the system can be obtained from

$\operatorname{COP} P_{c_{m} m}=\frac{Q_{\text {evap }}}{W_{\text {in }_{m}}}$

\section{Iv. Uncertainty Analysis}

The uncertainty analysis for the calculated parameters of the experimental AAC system, namely the cooling capacity, refrigerant mass flow rate, compressor power, $\mathrm{COP}$ and rate of total exergy destruction in the refrigeration circuit of the system, was performed using the method given by Moffat (1988). According to this method, the function R is assumed to be calculated from a set of totally $\mathrm{N}$ measurements (independent variables) represented by

$R=R\left(X_{1}, X_{2}, X_{a}, \ldots, X_{N}\right)$

Then the uncertainty of the result R can be determined by combining the uncertainties of the individual terms using a root-sum-square method, i.e.

$\delta R=\sqrt{\sum_{\mathrm{i}=1}^{N}\left(\frac{\partial R}{\partial X_{\mathrm{i}}} \partial X_{\mathrm{i}}\right)^{2}}$

Using the accuracies for various measured variables presented in Table 1, the uncertainties of the calculated parameters were determined with the evaluation of Eqs.(1), (2), (3), (4), and (5).

The total uncertainties of $\mathrm{Q}_{\text {ewap }}, \mathrm{m}_{\mathrm{r}}, \mathrm{W}_{\text {comp }}$ and COP estimated by the analysis are $4.8 \%, 4.7 \%, 4.9 \%$ and $6.8 \%$ respectively.

\section{v. Testing Procedure}

Performance tests were carried out at six different compressor speeds, namely 800, 1200, 1600, 2000, 2400 and $2800 \mathrm{rpm}$. In all tests the indoor coil air flow rate was adjusted to its maximum $\left(0.158 \mathrm{~m}^{3} / \mathrm{s}\right)$, while in the tests using ambient air as heat sources the outdoor unit air flow rate was also adjusted to its maximum $\left(0.728 \mathrm{~m}^{3} / \mathrm{s}\right)$. Before performing the tests, the air temperatures at the inlets of the evaporator ( $T_{\text {evap, }}$, ain) and condenser ( $\left.T_{\text {cond, aout }}\right)$ were both fixed to either 5,10 or $15^{\circ} \mathrm{C}$. Data was collected until the steady-state was achieved, which took a time period of $10-15 \mathrm{~min}$. During the tests discharge pressure nerver exceeded 16 bar which was the maximum test pressure of the indoor coil. Using data acquired in the test operations, the air temperature at the outlet of the indoor unit, heating capacity, $C O P_{h}$ and $C O P_{h m}$ in the AHP system were evaluated.

\section{Results and Discussion}

Various performance parameters of the experimental system for AHP tests are shown in Figures 2-9. The conditioned air temperature at the outlet of the indoor unit and compressor discharge temperature were shown in Fig.2 and Fig.3, respectively. The conditioned air temperature increases with compressor speed, and the higher the set of air inlet temperatures, the higher the conditioned air temperature. The compressor discharge temperature rises with increasing compressor speed, and it increases with rising air inlet temperature set.

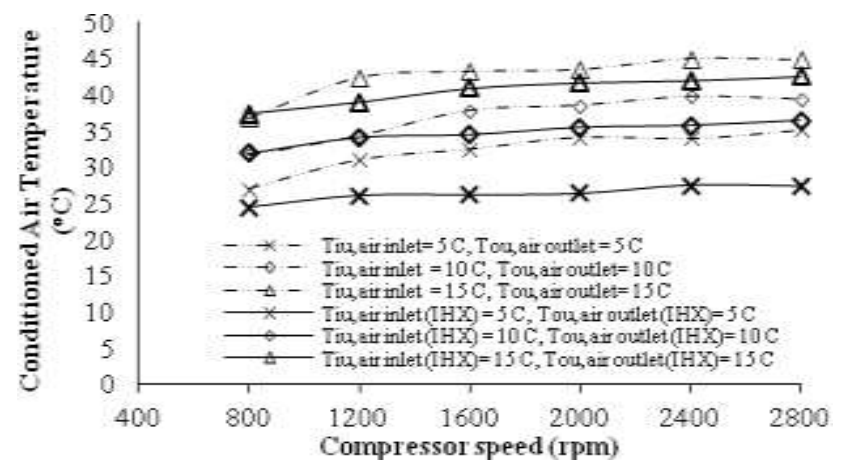

Figure 2. Variations in the discharge temperature with compressor speed.

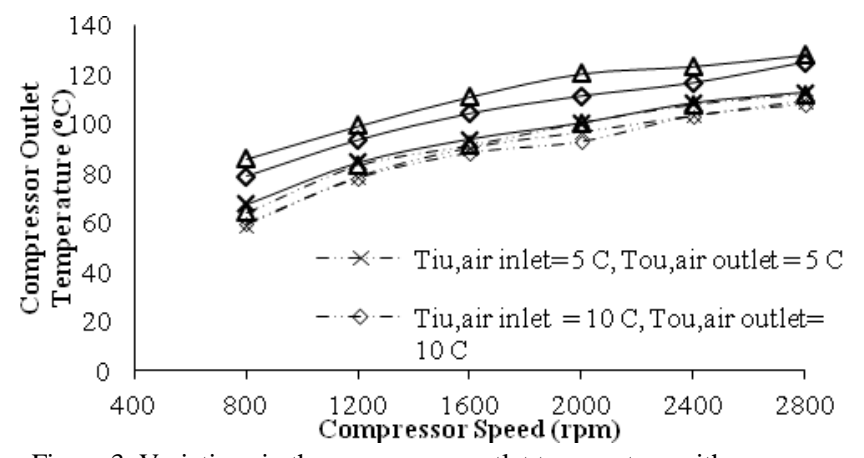

Figure 3. Variations in the compressor outlet temperature with compressor speed.

The heating capacity and refrigerant mass flow rate were shown in Fig.4 and Fig.5, respectively. The heating capacity increases considerably with the compressor speed, while the refrigerant mass flow increases slightly with it. It is seen that the heating capacity and refrigerant mass flow rate rise with increasing air inlet temperature set. 
Proc. of the Fourth International Conference on Advances in Mechanical and Robotics Engineering - AMRE 2016.

Copyright $($ Institute of Research Engineers and Doctors. All rights reserved.

ISBN: 978-1-63248-115-3 doi: 10.15224/ 978-1-63248-115-3-57

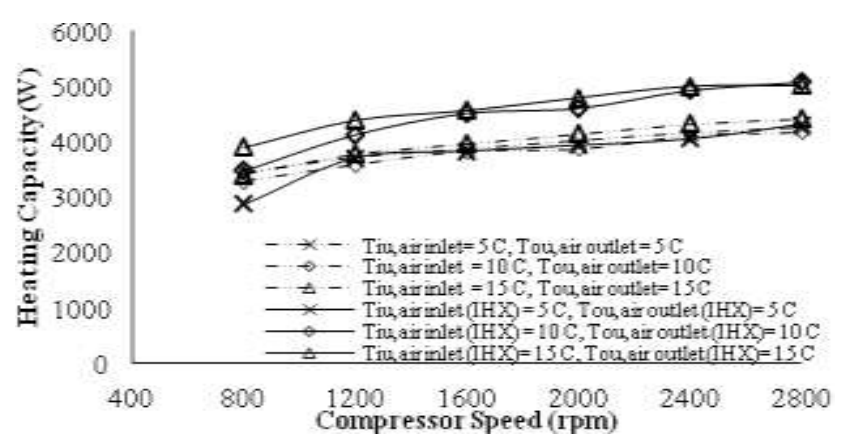

Figure 4. Variations in the heating capacity with compressor speed.

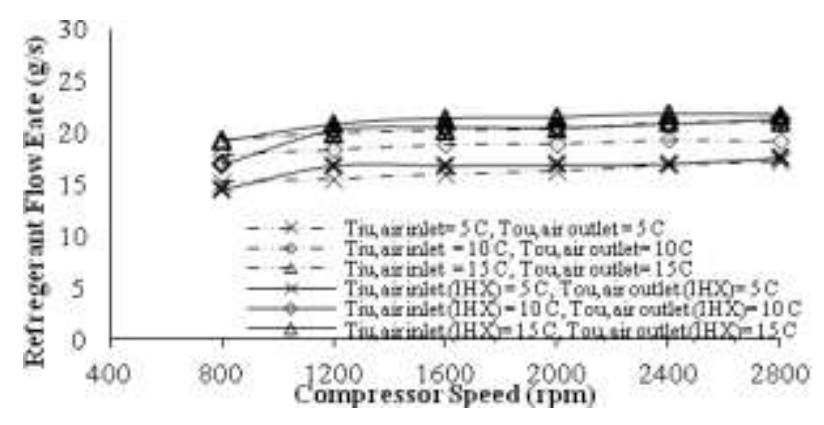

Figure 5. Variations in the mass flow rate with compressor speed.

The compressor power and compressor shaft power were shown in Fig.7 and Fig.8, respectively. It is seen that both compressor powers rise with increasing compressor speed, and both compressor powers increase with rising inlet air temperature set with and without IHX.

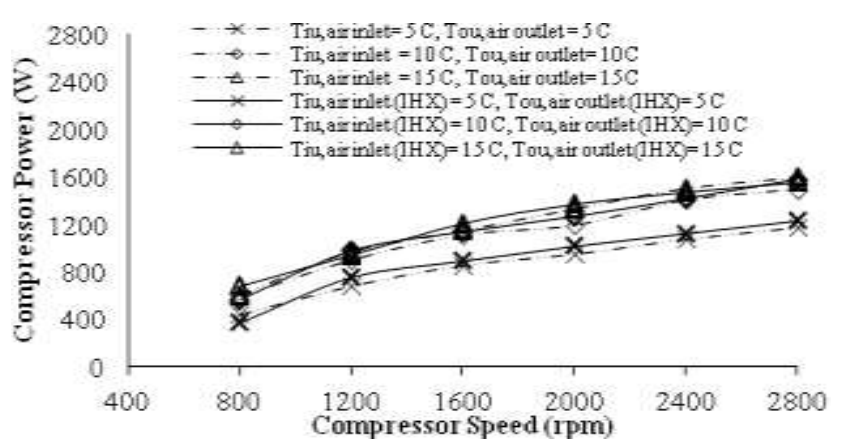

Figure 6. Variations in the compressor power rate with compressor speed.

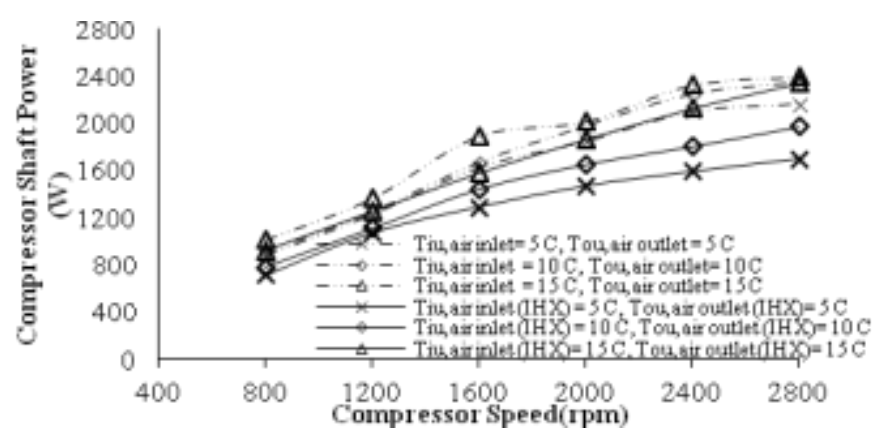

Figure 6. Variations in the compressor shaft power with compressor speed.

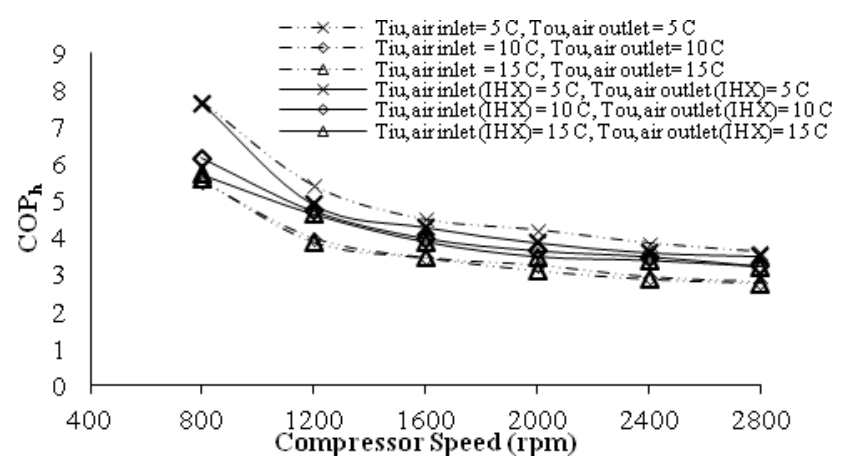

Figure 8. Variations in $\mathrm{COP}_{\mathrm{h}}$ with compressor speed.

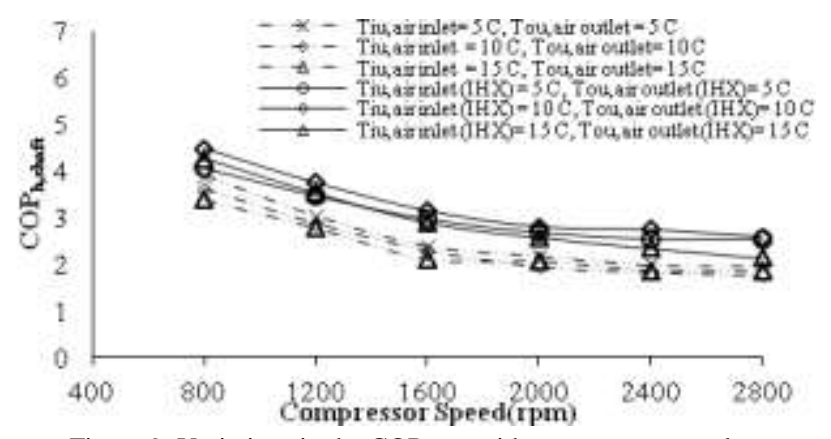

Figure 9. Variations in the $\mathrm{COP}_{\mathrm{h} \text {,shaft }}$ with compressor speed.

The coefficient of performance for heating and the coefficient of performance based on compressor shaft power input were shown in Figure 10 (a) and (b), respectively. Both heating capacity and compressor power increase with rising compressor speed. However, because compressor power increases faster than the heating capacity does, both the $\mathrm{COP}_{h}$ and $\mathrm{COP}_{\mathrm{h}, \mathrm{m}}$ decrease with it. It is seen that the lower the air inlet temperature set, the higher the $\mathrm{COP}_{\mathrm{h}}$ and $\mathrm{COP}_{\mathrm{h}, \mathrm{m}}$.

\section{vII. Conclusions}

Various performance parameters of an automotive AAC/AHP system with IHX using R134a as the working fluid have been experimentally evaluated in both air conditioning and heat pump operations. The final conclusions reached in this study are as follows.

* The conditioned air temperature at the outlet of indoor unit decrease with compressor speed in AAC mode, while it increases with compressor speed in AHP mode. Although the conditioned air temperatures for $5^{\circ} \mathrm{C}$ air inlet temperature set are not sufficiently high, the AHP system provided high enough air temperatures reached after $10^{\circ} \mathrm{C}$ air inlet temperature set.

* In the AHP system with and without IHX, heating capacities of the system increase with compressor speed. The AHP system provided insufficient heating capacity for $5^{\circ} \mathrm{C}$ air inlet temperature set. Therefore, the air-sourced AHP system looks like it cannot provide sufficient heating capacity at severe winter conditions, and it can be used as a supplemental heating system. Furthermore using IHX for 10 and $15^{\circ} \mathrm{C}$ air inlet temperature heating capacity increases fairly. 
* Both COP of the system with and without IHX for heating modes drop with rising compressor speed. Although the AHP provides insufficient heating capacity, it provides heating with $C O P$ values of as high as 6 , which is 1 for electric heating. This means that AHP system can perform heating with a high energetic performance compared to its alternatives.

\section{Acknowledgment}

The authors would like to acknowledge the support provided by Kocaeli University under the project number $2014 / 51$

\section{References}

[1] J. Meyer, G. Yang, E. Papoulis, "R134a heat pump for improved passenger comfort", SAE Technical Papers, Paper Code 2004-01-1379, 2004

[2] J.V.C. Vargas, J.A.R. Parise "Simulation in transient regime of a heat pump with closed-loop and on-off control" Int. J. Refrig. 1995, 18, 235-43.

[3] D. Antonijevic, R. Heckt, "Heat pump supplemental heating system for motor vehicles" Proc. Inst. Mech. Eng., D. J. Automob. Eng., 2004, 218;pp1111-1115.

[4] E.R. Domitrovic, V.C. Mei, F.C. Chen, "Simulation of an automotive heat pump" ASHRAE Trans, 1997, vol.103, pp. 291-96.

[5] M, Hosoz, M. Direk, "Performance evaluation of an integrated automotive air conditioning and heat pump system" Energy Convers Manag, 2006, 47, pp.545-559.

[6] J. Rongstam, F.A. Mingrino "a coolant-based automotive heat pump system" Vehicle Thermal Management Systems Conference (VTMS6) Proceedings; SAE Paper Code C599/067/2003, 2003.

[7] D.Y. Lee, C.W. Cho, J.P. Won, Y.J. Park, M.Y. Lee, "Performance characteristics of mobile heat pump for a large passenger electric vehicle" Appl. Therm. Eng. 2013, 50, pp.660-669.

[8] L.P. Scherer, M. Ghodbane, J. A. Baker,P. S. Kadle, "Vehicle performance comparison of an R-152a and R-134a heat pump system" SAE Technical Papers, Paper code 2003-01-0733; 2003.

[9] M. Direk, M. Hosoz, Energy and exergy analysis of an automobile heat pump system, Int J Exergy 2008; 5; 556-66.

[10] T. Tamura, Y. Yakumaru, F. Nishiwaki, "Experimental study on automotive cooling and heating air conditioning system using $\mathrm{CO} 2$ as a refrigerant" Int J Refrig 2005, 28, 1302-07.

[11] S.C. Kim,M. S. Kim, I. C. Hwang, T. W. Lim, "Heating performance enhancement of a $\mathrm{CO} 2$ heat pump system recovering stack exhaust" thermal energy in fuel cell vehicles. Int J Refrig 2007; 30; 1215-26.

\begin{tabular}{c} 
About Author (s): \\
$\begin{array}{c}\text { Erkutay TAŞDEMIRCI } \\
\text { Automotive Engineering Department of } \\
\text { Kocaeli University. }\end{array}$ \\
$\begin{array}{c}\text { Asst. Prof. Ertan ALPTEKIN } \\
\text { Professor in Technology Faculity } \\
\text { Automotive Engineering Department of } \\
\text { Kocaeli University. }\end{array}$ \\
\hline
\end{tabular}

Prof. Dr. Murat HOSÖZ

Professor in Technology Faculity Automotive Engineering Department of Kocaeli University. 